\title{
Efektivitas model pembelajaran jigsaw berbasis lesson study sebagai upaya perbaikan proses dan hasil belajar mahasiswa
}

\author{
Mufida Nofiana ${ }^{1 *}$, Arief Husin ${ }^{2}$, Arum Adita ${ }^{3}$, Listika Yusi Risnani ${ }^{4}$ \\ Program Studi Pendidikan Biologi, Fakultas Keguruan dan Ilmu Pendidikan \\ Universitas Muhammadiyah Purwokerto, Jl. Raya Dukuhwaluh PO BOX 202, Purwokerto 53182 \\ ${ }^{1}$ mufidanofiana@ump.ac.id*; ${ }^{2}$ ariefhusin@ump.ac.id; ${ }^{3}$ arumadita@ump.ac.id; ${ }^{4}$ listikayusirisnani@ump.ac.id \\ *korespondensi penulis
}

\section{Abstrak}

Tujuan penelitian ini adalah untuk mengetahui efektivitas model pembelajaran jigsaw berbasis lesson study sebagai upaya perbaikan proses dan hasil belajar mahasiswa pada mata kuliah perkembangan hewan. Subyek penelitian adalah mahasiswa semester 4 Tahun Akademik 2018/2019. Pelaksanaan lesson study berlangsung selama 3 siklus terdiri dari kegiatan PlanDo-See. Pada kegiatan lesson study, dosen menggunakan model jigsaw yang dimodifikasi sesuai keadaan kelas (temuan observer). Hasil pelaksanaan Lesson study menunjukkan perubahan yang cukup signifikan terhadap peningkatan proses belajar mahasiswa. Hal tersebut terlihat dari temuan observer yang menyatakan bahwa pembelajaran dalam kelompok asal sudah terlihat baik setelah dilaksanakan lesson study selama 3 siklus (80\% mahasiswa antusias mengikuti perkuliahan dengan penerapan model jigsaw), kerjasama anggota kelompok terlihat baik (mahasiswa saling mengkonfirmasi pendapat dan saling membantu mencari solusi atas permasalahan yang ditemukan, saling membantu dalam memahami konsep materi), hampir semua anggota kelompok di dalam kelompok asal aktif memberikan pendapat, diskusi kelompok terlihat hidup (antusias mahasiswa dalam berdiskusi dengan teman terkait topik materi meningkat). Meskipun belum seluruh mahasiswa dapat berpartisipasi aktif dalam diskusi kelompok, namun seluruh mahasiswa memperhatikan informasi yang disampaikan oleh teman ahli. Hasil analisis kegiatan lesson study terhadap hasil belajar mahasiswa di dalam kelompok asal menunjukkan bahwa $80 \%$ mahasiswa memiliki hasil belajar yang baik dilihat dari hasil belajar kelompoknya. Penerapan model pembelajaran jigsaw juga telah mampu meningkatkan pemahaman konsep sebagian besar mahasiswa secara individu, yang terlihat dari 74\% mahasiswa memperoleh nilai diatas atau sama dengan C.

Kata kunci: Lesson study, Jigsaw, Proses Pembelajaran, Hasil Belajar

\begin{abstract}
The purpose of this research is to study jigsaw learning models based on lesson study as an effort to improve the process and student learning outcomes in animal development courses. The research subjects were semester 4 students of Academic Year 2018/2019. The lesson study lasts for 3 cycles consisting of Plan-Do-See activities. In lesson study activities, the lecturer uses a jigsaw model that is appropriate to the class (observer's findings). The results of this research showed a significant change in the improvement of student learning processes. This can be seen from the observers' findings which state that learning in the original group has been seen to be good after learning for 3 cycles $(80 \%$ of students are enthusiastic about attending lectures with the
\end{abstract}


application of a jigsaw model), cooperative group members look positive (students who exchange support, and help each other looking for solutions to the above found, helping each other in the concept of the material), almost all group members in the original group, group discussion looks lively (enthusiastic students in discussions with friends related to the topic of material increases). Although not all students can discuss actively in group discussions, but all students pay attention to the information conveyed by expert friends. The results of the analysis of lesson study activities on student learning outcomes in the original group showed $80 \%$ of students had good learning outcomes seen from the group learning outcomes. The application of the jigsaw learning model has also increased the understanding of concepts of large students, which is seen from $74 \%$ of students getting more than or equal to $\mathrm{C}$

Keywords: Lesson study, Jigsaw, Learning process, Learning Outcomes

\section{PENDAHULUAN}

Proses pembelajaran di perguruan tinggi membutuhkan kemandirian belajar mahasiswa sebagai upaya mencapai kesuksesan belajar. Kemandirian belajar dapat tercipta melalui strategi pembelajaran yang mampu memfasilitasi mahasiswa menyelesaikan masalah terkait topik materi yang diajarkan. Oleh karena itu, dosen dapat merancang perkuliahan menggunakan strategi yang menuntut mahasiswa untuk bekerjasama, berkolaborasi, memecahkan masalah, berpikir kritis, maupun berpikir kreatif dalam menyelesaikan topik materi perkuliahan.

Penentuan strategi perkuliahan yang tepat didukung oleh beberapa factor seperti: karakteristik mahasiswa, kemampuan kognitif mahasiswa, jenis topik atau materi yang akan diajarkan, serta fasilitas pendukung perkuliahan yang tersedia. Oleh karena itu, setiap dosen wajib melakukan refleksi pembelajaran dalam rangka mencapai tujuan pembelajaran yang optimal. Refleksi pembelajaran tersebut dapat dilakukan secara mandiri maupun melalui feedback dan evaluasi dari mahasiswa serta teman sejawat. Salah satu bentuk refleksi pembelajaran yang dapat dilakukan oleh dosen adalah melalui kegiatan lesson study.

Lesson study adalah suatu proses peningkatan pembelajaran yang dilakukan secara kolaboratif oleh sekelompok pendidik dengan dimulai dari: mengidentifikasi suatu masalah, merancang skenario pembelajaran untuk menyelesaikan masalah yang ditemukan, membelajarkan siswa sesuai dengan skenario, mengevaluasi dan merevisi skenario pembelajaran, membelajarkan lagi skenario pembelajaran yang telah direvisi, mengevaluasi kembali proses pembelajaran yang berlangsung serta terakhir membagikan hasil pengamatan proses pembelajaran kepada pendidik yang lain (Susilo, 2013). Focus Lesson study adalah 
peningkatan pembelajaran (Zubaidah, 2010). Dalam hal ini, melalui hasil kegiatan pengamatan yang dilakukan terhadap proses pembelajaran, pendidik hendaknya memikirkan cara bagaimana meningkatkan kegiatan belajar siswa dan kemampuan berpikir siswa. Kegiatan lesson study tidak terbatas pada satu topik pembelajaran, namun dilakukan secara berkelanjutan dalam rangka perbaikan proses pembelajaran dan pencapaian tujuan pembelajaran.

Teacher Institute (2008) mengemukakan tentang tahapan Lesson study yang terdiri dari 3 tahapan yakni Plan- Do- See.

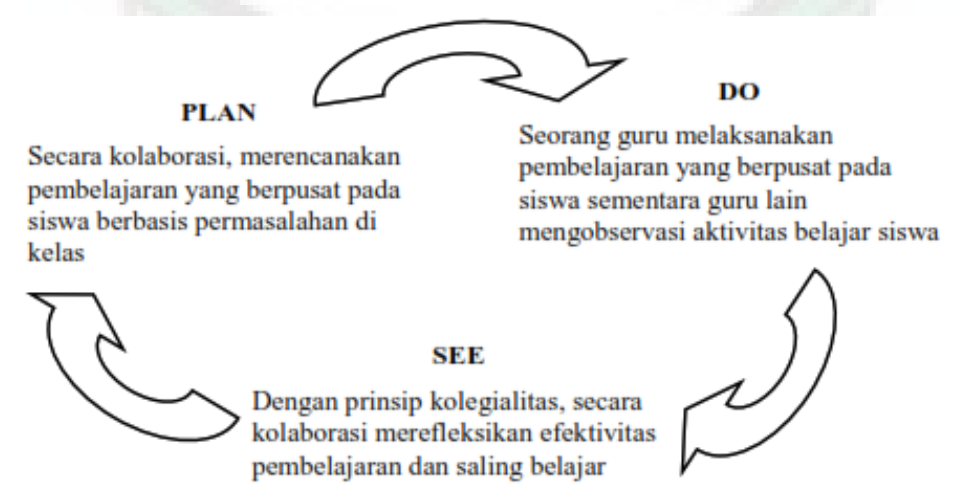

Gambar 1. Rancangan Siklus Lesson study

Pelaksanaan Lesson study diawali dari tahap perencanaan (plan). Tahap ini bertujuan merancang pembelajaran yang membelajarkan siswa seperti bagaimana siswa dapat berperan aktif dalam proses pembelajaran, terlibat dalam penemuan konsep materi, maupun menunjukkan sikap positif dalam pembelajaran. Dalam tahap perencanaan, dosen melakukan kolaborasi dengan dosen lain dalam merencanakan pembelajaran yang menarik dan mampu mengaktifkan siswa. Tujuan dari kolaborasi yang dilakukan adalah untuk memperkaya ide-ide terhadap solusi yang akan diputuskan. Tahap perencanaan diawali dengan analisis permasalahan yang dihadapi dalam pembelajaran. Dosen dan tim dosen lain selanjutnya berkolaborasi untuk mencari solusi atas permasalahan yang dihadapi. Solusi yang diputuskan kemudian dituangkan dalam rancangan pembelajaran atau lesson plan, teaching materials berupa media pembelajaran dan lembar kerja mahasiswa serta metode evaluasi. Zubaidah (2010) mengemukakan tahap plan mencakup 4 langkah yakni: menganalisis topik, menganalisis realitas siswa, membuat rencana pembelajaran, dan memeriksa rencana pembelajaran 
Tahap kedua dalam Lesson study adalah pelaksanaan (Do). Tahap ini merupakan penerapan dari rancangan pembelajaran yang telah dirumuskan pada tahap perencanaan. Tahap pelaksanaan bertujuan untuk menguji efektivitas model pembelajaran yang telah dirancang. Tahap ini membutuhkan dosen lain yang berperan sebagai observer (pengamat) pembelajaran. Sebelum pembelajaran dimulai, dosen model melakukan koordinasi dengan pengamat terkait dengan rancangan pembelajaran yang akan digunakan serta mengingatkan bahwa selama kegiatan pembelajaran berlangsung pengamat tidak mengganggu kegiatan pembelajaran dan hanya mengamati aktivitas siswa selama pembelajaran.

Fokus pengamatan ditunjukkan pada interaksi antar mahasiswa, mahasiswa-bahan aja, mahasiswa-dosen, dan mahasiswa-lingkungan. Lembar observasi dapat dikembangkan bersama antara dosen model dan pengamat. Pengamat selanjutnya dapat mengambil tempat di ruang kelas yang memungkinkan dapat mengamati aktivitas siswa.

Mahasiswa diupayakan dapat menjalani proses pembelajaran dalam setting yang wajar dan natural, tidak dalam keadaan under pressure yang disebabkan karena adanya program lesson study. Selama pembelajaran, pengamat dapat melakukan perekaman kegiatan pembelajaran melalui video atau foto untuk kepentingan dokumentasi dan bahan studi lebih lanjut. Pengamat melakukan pencatatan tentang perilaku belajar siswa selama pembelajaran berlangsung. Catatan dibuat berdasarkan pedoman dan urutan pengalaman belajar siswa yang tercantum dalam rancangan pembelajaran.

Tahap ketiga dalam kegiatan lesson study adalah refleksi (See). Setelah selesai pembelajaran langsung dilakukan diskusi antara dosen model dan pengamat. Pada tahap refleksi dosen model menceritakan kesulitan yang dialami selama proses pembelajaran, menceritakan perbedaan antara apa yang direncanakan dengan apa yang terjadi sesungguhnya, serta aspek-aspek pembelajaran yang diinginkan agar pengamat mengevaluasinya. Pengamat dalam tahap ini membicarakan secara spesifik tentang hal-hal yang telah dicatat, dan dalam menyampaikan sarannya harus didukung bukti-bukti yang diperoleh dari hasil pengamatan bukan berdasarkan opininya.

Hasil tahap refleksi (see) dapat dijadikan umpan balik untuk kepentingan perbaikan dan peningkatan proses pembelajaran. Hasil ini juga akan dipertimbangkan kembali untuk tahap plan dan do untuk perbaikan pembelajaran berikutnya. Oleh karena itu, tujuan dari penelitian ini 
adalah untuk mengetahui efektivitas model pembelajaran jigsaw berbasis lesson study sebagai upaya perbaikan proses dan hasil belajar mahasiswa pada mata kuliah perkembangan hewan.

\section{METODE}

Kegiatan lesson study yang dilakukan pada perkuliahan perkembangan hewan di program studi pendidikan biologi Universitas Muhammadiyah Purwokerto dilaksanakan pada mahasiswa semester 4 Tahun Akademik 2018/2019. Kegiatan tersebut dilaksanakan secara berkelanjutan selama 3 siklus.

Kegiatan lesson study diawali dengan membuat perencanaan (plan) tentang pembelajaran yang akan dilakukan. Pada pertemuan pertama kegiatan planning dilakukan melalui pertemuan antara dosen model dengan observer.

\section{a. Plan}

Kegiatan perencanaan diawali dari penyampaian kondisi kelas oleh dosen model kepada observer pembelajaran. Dosen model menyampaikan bahwa mahasiswa semester 4 yang menempuh mata kuliah perkembangan hewan memiliki kompetensi yang tidak sama, beberapa mahasiswa terlihat aktif dan memiliki kompetensi yang baik namun ada sebagian mahasiswa yang memiliki kompetensi yang kurang baik. Hal ini terlihat dari kemampuan berkomunikasi yang tidak merata, kemampuan berpendapat yang tidak menyeluruh, serta tanggung jawab belajar yang kurang pada beberapa mahasiswa khususnya mahasiswa dengan kompetensi yang kurang baik. Untuk mengatasi masalah tersebut, dosen model merencanakan akan menggunakan model pembelajaran jigsaw yang dimodifikasi sesuai keadaan kelas.

Pertimbangan pemilihan model jigsaw oleh dosen model disebabkan karena model tersebut memiliki beberapa kelebihan, Rusman (2012) menyebutkan kelebihan model jigsaw antara lain:

1. Meningkatkan rasa tanggung jawab siswa/ mahasiswa terhadap pembelajarannya sendiri dan juga pembelajaran orang lain.

2. Siswa/ mahasiswa tidak hanya mempelajari materi yang diberikan, tetapi mereka juga harus siap memberikan dan mengerjakan materi tersebut pada anggota kelompoknya yang lain, sehingga pengetahuannya jadi bertambah.

3. Menerima keragaman dan menjalin hubungan sosial yang baik dalam hubungan belajar.

4. Meningkatkan kerja sama secara kooperatif untuk mempelajari materi yang ditugaskan. 
Adapun perencanaan pembelajaran jigsaw yang dilakukan oleh dosen model pada mata kuliah perkembangan hewan dimodifikasi dari Arosson (1978) sebagai berikut:

1. Membentuk 4 kelompok yang terdiri dari 7-8 mahasiswa

2. Masing-masing anggota kelompok selanjutnya dibagi berdasarkan topik yang disediakan untuk menjadi ahli topik di kelompoknya

3. Masing-masing ahli berkumpul menjadi kelompok ahli

4. Ahli mendiskusikan tentang topik yang diberikan oleh dosen

5. Presentasikan hasil diskusi tersebut di depan kelas

6. Ahli kembali ke kelompok asal untuk menyampaikan informasi kepada anggota kelompok terkait topik yang dipresentasikan/ hal yang belum dipahami dalam topik tsb

7. Evaluasi dengan mengerjakan LKM (lembar kerja mahasiswa)

Selain menyiapkan perencanaan pembelajaran, dosen model juga menyiapkan instrument yang akan diisi oleh observer pembelajaran. Instrument tersebut berupa lembar observasi yang berisi nama kelompok dan anggotanya.

\section{b. Do}

Pelaksanaan pembelajaran (Do) dilaksanakan melalui kegiatan open class yang dihadiri oleh beberapa dosen untuk mengamati proses pelaksanaan perkuliahan yang berlangsung. Observer yang melakukan observasi sebanyak 3 orang (Drs. Arief Husin, M.Si., Arum Adita, M.Pd, dan Listika Yusi Risnani, M.Pd). Observer melakukan pengamatan dan mencatat hal-hal yang menjadi temuan.nya. Hal yang menjadi temuan tersebut adalah kejadian yang menarik terkait dengan proses pembelajaran, sikap mahasiswa, dan tanggung jawab belajar mahasiswa. Observer melengkapi catatan temuannya dengan foto atau video proses pembelajaran pada masing-masing kelompok yang menjadi objek pengamatan.

\section{c. See}

Kegiatan see pada tahapan lesson study merupakan kegiatan refleksi atas pembelajaran yang telah dilakukan oleh dosen model. Kegiatan ini dilakukan setelah proses pembelajaran selesai dilakukan. Pada kegiatan see observer menyampaikan hal-hal yang menjadi temuannya. 


\section{HASIL DAN PEMBAHASAN}

Pada kegiatan lesson study siklus 1, observer masih banyak menemukan mahasiswa yang belum fokus dalam perkuliahan seperti bermain hp, melamun, serta membahas topik di luar topik perkuliahan. Kemampuan komunikasi mahasiswa juga belum merata terlihat dari hanya beberapa mahasiswa yang bertanya maupun berpendapat serta berdiskusi untuk menyelesaikan masalah dari topik yang diberikan dosen. Kemandirian belajar mahasiswa belum terbangun, terlihat dari antusias mahasiswa yang masih kurang pada saat mendengarkan informasi yang disampaikan oleh teman ahli maupun berkolaborasi dengan teman kelompok dalam menyelesaikan topik materi.

Fokus perhatian dari temuan observer didasarkan pada hal-hal yang masih belum sesuai antara lain: Anggota tim asal terlalu banyak, teman yang berperan sebagai ahli tidak tampak sebagai ahli di kelompok asal, diskusi di kelompok asal masih belum terjadi, pembelajaran SCL yang bersifat kolaboratif belum efektif dilaksanakan oleh mahasiswa.

Temuan dan masukan dari observer menjadi perhatian dosen model sehingga dilakukan perbaikan pembelajaran untuk pelaksanaan lesson study siklus 2 sebagai berikut:

1. Kelompok asal dibagi lagi menjadi 6 kelompok sehingga masing-masing kelompok terdiri 45 mahasiswa

2. Re-organisasi kelompok asal dan ahli untuk topik 5 dan 7

3. Tim ahli tetap berdiskusi untuk menyampaikan hal yang berkaitan dengan topik keahlian, untuk menjamin kebenaran konsep materi yang akan disampaiakan oleh ahli hasil diskusi diserahkan ke dosen

4. Ahli menyampaikan hasil diskusi ke kelompok asal

5. Diskusi terjadi di kelompok asal, apabila ahli di kelompok tersebut belum memiliki jawaban, masalah disampaikan ke kelas

6. 1-2 Kelompok asal akan maju menyampaikan topik yang dipelajari dari sang ahli, hasil diskusi yang berlangsung di kelompok, hasil diskusi yang ada di LKM

Setelah dilakukan revisi perencanaan proses pembelajaran, pembelajaran pada lesson study siklus II berlangsung lebih kondusif terlihat dari antusias mahasiswa dalam berdiskusi di kelompok asal. Jumlah anggota kelompok asal yang lebih kecil dari sebelumnya memungkinkan mahasiswa mampu berkomunikasi antara satu dengan lainnya secara lebih baik. Ahli materi pada 
kelompok tersebut tampak menguasai materi dan menyampaikan materi kepada seluruh anggota kelompok. Seluruh anggota kelompok mendengarkan materi yang disampaikan ahli dan terlihat semua mahasiswa belajar bersama dalam kelompoknya. Ketika diberikan LKM oleh dosen, semua anggota kelompok sama-sama bertanggung jawab terhadap hasil belajar kelompok sehingga tampak terjadi peningkatan partisipasi mahasiswa melalui diskusi.

Observer memberikan masukan terkait dengan hasil refleksi pembelajaran pada LS II antara lain: untuk meningkatkan tanggung jawab dan keaktifan mahasiswa dalam berdiskusi, mahasiswa diminta untuk membuat kesimpulan materi di akhir pertemuan, kemudian menunjuk mahasiswa secara random untuk mengetahui pemahaman konsep materi pada topik yang dipelajari. Oleh karena itu, pada pelaksanaan lesson study siklus III dilakukan revisi terhadap perencanaan pembelajaran sebagai berikut:

1. Sebelum melaksanakan proses perkuliahan, dosen menyampaikan bahwa seluruh mahasiswa wajib membuat kesimpulan terkait topik/materi yang dipelajari pada saat itu

2. Dosen akan menunjuk mahasiswa secara random untuk menyampaikan kesimpulan pembelajaran.

Hasil pelaksanaan Lesson study di skilus III menunjukkan perubahan yang cukup signifikan terhadap peningkatan proses belajar mahasiswa. Hal tersebut terlihat dari temuan yang disampaikan oleh observer yang menyatakan bahwa pembelajaran dalam kelompok asal sudah terlihat baik ( $80 \%$ mahasiswa antusias mengikuti perkuliahan dengan penerapan model jigsaw), kerjasama anggota kelompok terlihat baik (mahasiswa saling mengkonfirmasi pendapat dan saling membantu mencari solusi atas permasalahan yang ditemukan, saling membantu dalam memahami konsep materi), hampir semua anggota kelompok di dalam kelompok asal aktif memberikan pendapat, diskusi kelompok terlihat hidup (antusias mahasiswa dalam berdiskusi dengan teman terkait topik materi meningkat). Meskipun belum seluruh mahasiswa dapat berpartisipasi aktif dalam diskusi kelompok, namun seluruh mahasiswa memperhatikan informasi yang disampaikan oleh teman ahli. Oleh karena itu, proses pembelajaran dengan menerapkan model jigsaw berbasis lesson study pada mata kuliah perkembangan hewan dapat meningkatan proses pembelajaran menjadi lebih baik.

Penelitian ini sejalan dengan penelitian Arjanggi (2013) yang menyebutkan bahwa pembelajaran dengan model jigsaw mampu meningkatkan kemampuan regulasi diri mahasiswa dalam belajarnya. Hal ini disebabkan karena model jigsaw mampu memfasilitasi mahasiswa 
yang kemampuannya kurang untuk meningkatkan pemahamannya melalui kerjasama dan saling membantu dalam memahami materi pembelajaran dengan mahasiswa yang kemampuannya lebih di dalam satu kelompoknya.

Model pembelajaran jigsaw juga dapat meningkatkan kemampuan kerjsama dan komunikasi mahasiswa dalam kelompok. Hal ini disebabkan karena melalui model pembelajaran jigsaw, dosen memberikan kesempatan mahasiswa untuk bekerjasama dan saling ketergantungan antar anggota kelompok untuk mempelajari suatu topik materi. Kesempatan tersebut memungkinkan mahasiswa memperoleh pemahaman yang menyeluruh sehingga menjadikan pembelajaran lebih efektif dan efisien. Pendapat tersebut dikuatkan dengan penelitian dari Alsa (2010) yang menyatakan bahwa model pembelajaran jigsaw dapat meningkatkan hubungan interpersonal peserta didik dan kerjasama kelompok.

Aronson (dalam Arjanggi, 2013) menambahkan bahwa pembelajaran kooperatif tipe jigsaw dapat menumbuhkan empati mahasiswa karena memberikan kesempatan mahasiswa untuk mengembangkan kemampuan memahami orang lain dalam kelompoknya. Dengan demikian pada model jigsaw yang digunakan dosen memungkinkan mahasiswa mencari strategi yang terbaik dalam mencapai tujuan belajar bersama.

Pembelajaran yang dilakukan diawali dengan pemberian masalah atau topik oleh dosen mata kuliah kepada kelompok ahli, selanjutnya kelompok ahli akan berdiskusi untuk menyelesaikan permasalahan tersebut. Pallenari (2012) menyebutkan bahwa beberapa masalah yang akan diselesaikan dalam kelompok ahli dapat menjadi cata efektif sebelum sharing informasi dengan kelompok asal. Untuk menjamin kebenaran hasil diskusi ahli, dosen meminta setiap kelompok ahli menuliskan dan menyerahkan hasil diskusinya. Hasil diskusi ahli selanjutnya akan disampaikan kepada kelompok asal, ahli dan anggota kelompok asal dapat melakukan tanya jawab dan berdiskusi lebih lanjut terkait topik atau permasalahan tersebut. Diskusi yang terjadi di dalam kelompok asal akan memungkinkan mahasiswa dapat saling belajar untuk mencapai tujuan pembelajaran. Dengan demikian, peserta didik memiliki tanggung jawab untuk memberikan tutor sebaya kepada sesama anggota kelompoknya.

Hasil refleksi penerapan model pembelajaran jigsaw berbasis lesson study pada mata kuliah perkembangan hewan mendapatkan informasi tentang kelebihan dan kekurangan dari penerapan model tersebut. Kelebihan dari model jigsaw antara lain: mahasiswa tidak takut bertanya dan sharing dalam diskusi, mahasiswa dapat memahami materi lebih cepat dan efektif, mahasiswa 
lebih aktif, materi lebih banyak yang diingat, tidak membosankan, dapat belajar secara mandiri, ahli lebih menguasi topik yang didiskusikan dan dapat menjadi tutuor sebaya, serta meningkatkan motivasi belajar. Kelemahan dari model jigsaw antara lain: jika ahli/ presenter kuran memahami materi yang disampaikan akan menghambat proses diskusi, banyak waktu terbuang karena mahasiswa masih ada yang berdiskusi di luar topik materi, tidak semua mahasiswa aktif, waktu untuk berdiskusi kurang, kurangnya penjelasan dari dosen, serta anggota kelompok asal kurang memperoleh penjelasan yang tuntas dari ahli/ presenter.

Penerapan model pembelajaran jigsaw berbasis lesson study yang dilakukan pada mata kuliah perkembangan hewan selain mampu meningkat proses belajar mahasiswa juga mampu meningkatkan profesionalisme dosen model melalui kegiatan refleksi. Hal ini sesuai dengan penelitian dari Cheung, Ming \& Yee Wong (2014) yang menyebutkan bahwa pembelajaran dengan lesson studi membantu guru untuk merefleksi kegiatan pembelajaran dan meningkatkan hasil belajar mahasiswa. Kegiatan refleksi akan memungkinkan dosen model mendapatkan gambaran proses pembelajaran di kelas, apakah telah sesuai dengan target, aktivitas yang berpusat pada mahasiswa, respon mahasiswa terhadap proses pembelajaran, serta keberhasilan belajar mahasiswa di akhir perkuliahan. Refleksi yang dilakukan oleh dosen model secara berkelanjutan akan memungkinkan terjadinya peningkatan proses pembelajaran mahasiswa menjadi lebih baik. Pernyataan tersebut sejalan dengan pemikiran Prihantoro (2012) yang meyebutkan bahwa peluang penerapan lesson study yang dilakukan pendidik dalam rangka peningkatan profesionalismenya antara lain: pendidik akan dapat mengkaji dan mengembangkan pembelajaran yang terbaik bagi peserta didik, dapat mengkaji secara cermat cara dan proses belajar serta tingkah laku peserta didik, merancang pembelajaran secara kolaboratif bersama pendidik lain, serta dapat melihat hasil pembelajaran sendiri melalui peserta didik dan kolega.

Hasil belajar mahasiswa selama pelaskanaan lesson study dilihat dari banyaknya pengetahuan atau materi yang diserap oleh mahasiswa. Hasil belajar tersebut diperoleh dari dua kegiatan, yakni evaluasi LKM di setiap akhir perkuliahan dan evaluasi mandiri melalui ujian tertulis. Hasil evaluasi belajar yang berupa evaluasi LKM merupakan hasil belajar bersama pada anggota kelompok asal. Dari hasil evaluasi LKM menunjukkan kemampuan mahasiswa dalam suatu kelompok untuk menyerap informasi melalui kegiatan problem solving. Nilai hasil belajar mahasiswa dalam kelompok asal disajikan pada grafik berikut. 


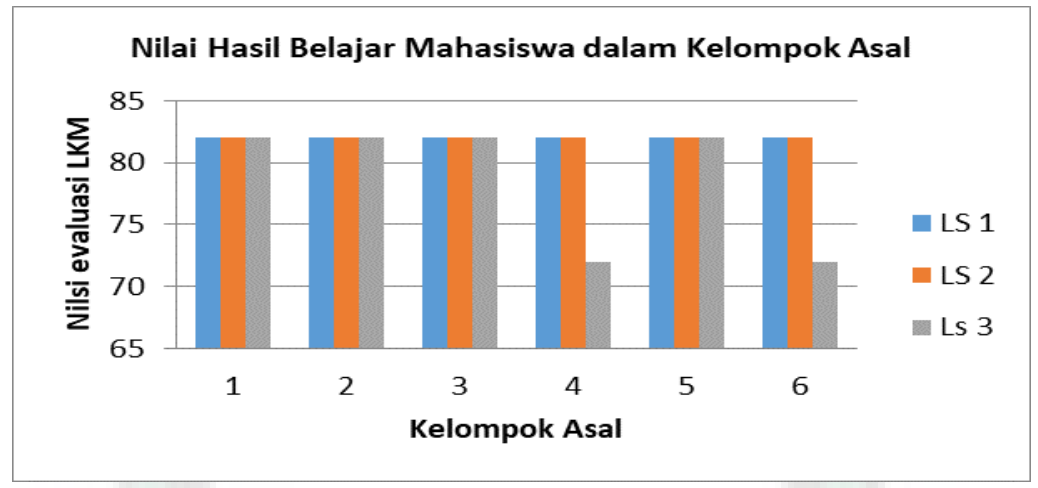

Grafik 1. Hasil belajar Mahasiswa dalam kelompok asal

Berdasarkan Grafik 1, diketahui bahwa pada LS 1 dan LS 2, mahasiswa mampu menyelesaikan masalah yang diberikan melalui diskusi kelompok, sedangkan pada LS 3 masih ada 2 kelompok yang tidak bisa menyelesaikan masalah dengan baik. Kegiatan pembelajaran dengan model jigsaw akan menuntut mahasiswa untuk melakukan pembelajaran kolaboratif bersama dengan teman kelompoknya. Melalui pembelajaran kolaboratif, mahasiswa dituntut bekerjasama dan terampil mengemukakan pendapat dari hasil pemikiran masing-masing dalam rangka membuat keputusan atau kesimpulan terkait penyelesaian masalah yang dihadapi kelompok. Hasil analisis kegiatan lesson study terhadap hasil belajar mahasiswa di dalam kelompok asal menunjukkan bahwa $80 \%$ mahasiswa memiliki hasil belajar yang baik dilihat dari hasil belajar kelompoknya.

Hasil penelitian yang telah dilakukan sejalan oleh hasil penelitian dari Clark \& Baker (2007) dan Setyosari (2009) yang mengatakan bahwa penerapan collaborative learning pada kelompok yang beragam melalui kegitan diskusi, klarifikasi gagasan, dan evaluasi dari orang lain akan memberikan hasil yang positif dalam menguatkan pemikiran kritis untuk mendapatkan pengetahuan factual. Hill \& Hill dalam Setyosari (2009) mengungkapkan bahwa keunggulan pembelajaran kolaborasi antara lain: (1) meningkatkan prestasi belajar, (2) meningkatkan pemahaman lebih mendalam, (3) mengembangkan keterampilan kepemimpinan, (4) meningkatkan sikap positif, (5) meningkatkan harga diri, (6) belajar secara inklusif, (7) merasa saling memiliki, dan (8) mengembangkan keterampilan masa depan.

Evaluasi mandiri yang dilakukan oleh dosen kepada mahasiswa bertujuan untuk mengetahui pemahaman materi yang diperoleh oleh setiap mahasiswa. Kegiatan evaluasi dilakukan melalui ujian tulis pada saat ujian tengah semester. Nilai hasil belajar mandiri mahasiswa disajikan pada grafik berikut: 


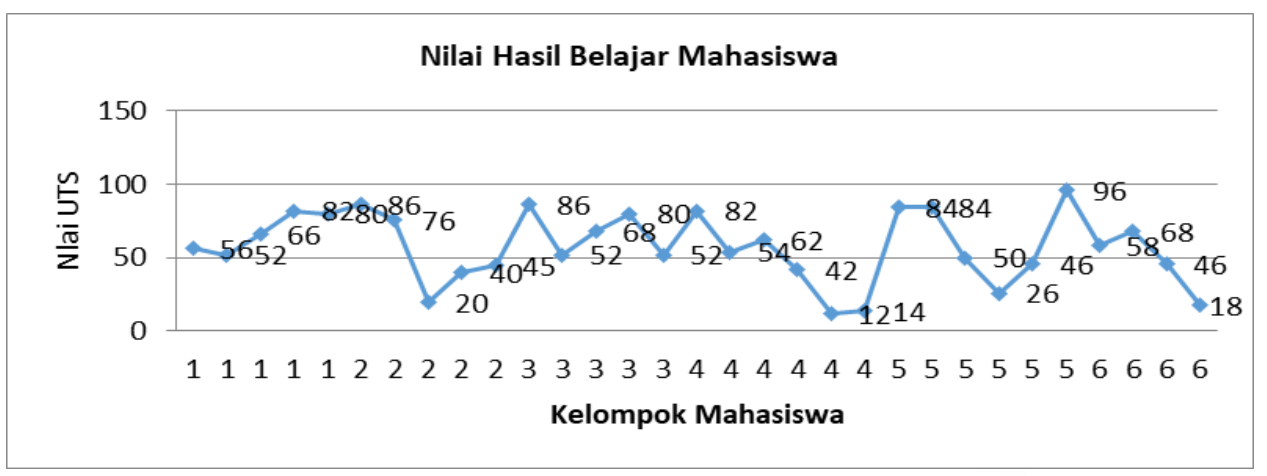

Grafik 2. Nilai Hasil belajar setiap mahasiswa setelah pelaksanaan lesson study

Berdasarkan Grafik 2, diketahui bahwa hasil belajar mahasiswa memilik nilai yang beragam. Nilai mahasiswa tersebut dapat dibuat peringkat sesuai peraturan akademik Universitas Muhammadiyah Purwokerto sebagai berikut:

\begin{tabular}{cc}
\hline Peringkat Nilai & Rentang nilai \\
\hline A & $X \geq 80$ \\
$B+$ & $X \geq 75$ \\
B & $X \geq 70$ \\
C+ & $X \geq 60$ \\
C & $X \geq 50$ \\
D & $X \geq 25$ \\
E & $X \geq 24$ \\
\hline
\end{tabular}

Sumber: Peraturan akademik UMP Tahun 2018

Berdasarkan hasil penelitian, prosentase nilai hasil belajar mahasiswa pada mata kuliah perkembangan hewan setelah dilakukan pembelajaran menggunakan model jigsaw berbasis lesson study sebagai berikut:

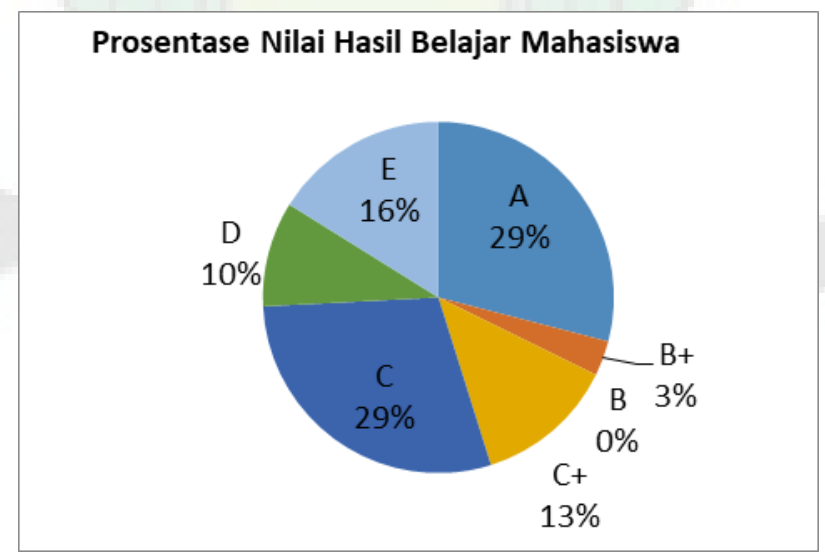

Diagram 1. Prosentase nilai hasil belajar mahasiswa

Berdasarkan Diagram 1, prosentase mahasiswa yang memperoleh nilai diatas atau sama dengan $\mathrm{C}$ sejumlah 74\%. Hal ini menunjukkan bahwa penerapan model pembelajaran jigsaw telah mampu meningkatkan pemahaman konsep sebagian besar mahasiswa secara individu. 
Penelitian ini sejalan dengan hasil penelitian darajran i Palennari (2011) yang menjelaskan bahwa strategi pembelajaran berpengaruh terhadap pemahaman konsep mahasiswa berkemampuan akademik berbeda, sehingga penggunaan integrasi strategi pembelajaran berbasis masalah dan jigsaw lebih meningkatkan pemahaman konsep mahasiswa.

Grafik 1 dan Diagram 1 menunjukkan bahwa masih terdapat mahasiswa yang memiliki nilai yang kurang atau masih belum lulus. Strategi pembelajaran jigsaw menuntut mahasisw a untuk aktif mencari konsep materi melalui kegiatan kolaborasi antar teman. Sintak pada strategi jigsaw secara tidak langsung menuntut kemandirian belajar dan tanggung jawab mahasiswa. jika dilihat dari hasil peneltian dapat dikatakan bahwa mahasiswa belum sepenuhnya memiliki kemandirian belajar yang baik. Kemandirian belajar adalah sikap dan kemampuan mahasiswa yang mampu berinisiatif, mengatasi masalah, mempunyai rasa percaya diri yang tinggi, keaktifan dan keterlibatan dalam proses pembelajaran. Kemandirian belajar berpengaruh terhadap keberhasilan proses belajar mahasiswa. hal ini seusai dengan hasil penelitian Rijal (2015) yang menyatakan bahwa terdapat hubungan yang positif antara kemandirian belajar siswa dengan hasil belajar kognitif biologi.

\section{SIMPULAN}

1. Pelaksanaan lesson study berlangsung selama 3 siklus, yang diawali dari kegiatan plando-see. Pada lesson study yang dilakukan, dosen menggunakan model jigsaw yang dimodifikasi sesuai keadaan kelas (temuan observer). Selama proses pelaksanaan lesson study terdapat perubahan yang cukup signifikan terhadap peningkatan proses belajar mahasiswa dan hasil belajar mahasiswa

2. Selama pelaksanaan lesson study, obsever banyak menemukan hal-hal yang menarik terkait dengan proses pembelajaran mahasiswa, antara lain: observer masih banyak menemukan mahasiswa yang belum fokus dalam perkuliahan seperti bermain hp, melamun, serta membahas topik di luar topik perkuliahan, kemampuan komunikasi mahasiswa juga tampak belum merata, serta kemandirian belajar mahasiswa belum terbangun.

3. Hasil pelaksanaan Lesson study menunjukkan perubahan yang cukup signifikan terhadap peningkatan proses belajar mahasiswa. Hal tersebut terlihat dari temuan yang disampaikan oleh observer yang menyatakan bahwa pembelajaran dalam kelompok asal sudah terlihat baik setelah dilaksanakan lesson study selama 3 siklus (80\% mahasiswa antusias mengikuti perkuliahan dengan penerapan model jigsaw), kerjasama anggota 
kelompok terlihat baik (mahasiswa saling mengkonfirmasi pendapat dan saling membantu mencari solusi atas permasalahan yang ditemukan, saling membantu dalam memahami konsep materi), hampir semua anggota kelompok di dalam kelompok asal aktif memberikan pendapat, diskusi kelompok terlihat hidup (antusias mahasiswa dalam berdiskusi dengan teman terkait topik materi meningkat). Meskipun belum seluruh mahasiswa dapat berpartisipasi aktif dalam diskusi kelompok, namun seluruh mahasiswa memperhatikan informasi yang disampaikan oleh teman ahli

4. Hasil belajar mahasiswa selama pelaskanaan lesson study dilihat dari banyaknya pengetahuan atau materi yang diserap oleh mahasiswa. Hasil belajar tersebut diperoleh dari dua kegiatan, yakni evaluasi LKM di setiap akhir perkuliahan dan evaluasi mandiri melalui ujian tertulis. Hasil analisis kegiatan lesson study terhadap hasil belajar mahasiswa di dalam kelompok asal menunjukkan bahwa $80 \%$ mahasiswa memiliki hasil belajar yang baik dilihat dari hasil belajar kelompoknya. Penerapan model pembelajaran jigsaw juga telah mampu meningkatkan pemahaman konsep sebagian besar mahasiswa secara individu yang terlihat dari $74 \%$ mahasiswa memperoleh nilai diatas atau sama dengan $\mathrm{C}$.

\section{REFERENSI}

Alsa, A. 2010. Pengaruh metode belajar Jigsaw terhadap keterampilan hubungan interpersonal dan kerjasama kelompok pada mahasiswa fakultas psikologi. Jurnal Psikologi, 37(2), 165-175.

Apriono, D. 2013. PEMBELAJARAN KOLABORATIF: Suatu Landasan untuk Membangun Kebersamaan dan Keterampilan. Diklus, 17(1).

Aronson, E. 1978. The jigsaw classroom. Sage.

Arjanggi, R., \& Setiowati, E. A. (2013). Meningkatkan belajar berdasar regulasi diri melalui pembelajaran kooperatif tipe jigsaw. Makara Seri Sosial Humaniora, 17(1), 55-63.

Clark, J., \& Baker, T. (2006, December). Collaborative learning in diverse groups: A New Zealand experience. In Proceedings of the 17th ISANA International Education Conference [CD ROM](pp. 5-8). Sydney: University of NSW.

Ming Cheung, W., \& Yee Wong, W. (2014). Does lesson study work? A systematic review on the effects of lesson study and learning study on teachers and students. International Journal for Lesson and Learning Studies, 3(2), 137-149.

Palennari, M. 2011. Potensi strategi integrasi PBL dengan pembelajaran kooperatif jigsaw dalam meningkatkan pemahaman konsep mahasiswa. Jurnal Biologi Edukasi, 3(2), 26-33.

Palennari, Muhiddin 2012. Potensi Integrasi Problem Based Learning dengan Pembelajaran Kooperatif Jigsaw Dalam Meningkatkan Keterampilan Berpikir Kritis Mahasiswa. bionature, 13(1). 
Prihantoro, R. 2011. Pengembangan Profesionalisme Guru Melalui Model Lesson study. Jurnal Pendidikan dan Kebudayaan, 17(1), 100-108.

Rijal, S., \& Bachtiar, S. (2015). Hubungan antara Sikap, Kemandirian Belajar, dan Gaya Belajar dengan Hasil Belajar Kognitif Siswa. Jurnal Bioedukatika, 3(2), 15-20.

Rusman. 2012. Model-model Pembelajaran: Mengembangkan Profesionalisme Guru. Jakarta: Rajawali Press.

Setyosari, P. 2009. Pembelajaran Kolaborasi: Landasan untuk mengembangkan keterampilan sosial, rasa saling menghargai dan tanggung jawab. Malang (Indonesia): Universitas Negeri Malang.

Susilo, H. 2005. Lesson study: Apa dan Mengapa. In Makalah pada Seminar dan Workshop Lesson study dalam rangka persiapan Kolaborasi FMIPA MGMP MIPA SMP dan SMA Kota Malang (Vol. 21).

Stepanek, J. 2003. A Lesson study team steps into the spotlight. Northwest Teacher, 4(3), 911.

Takahashi, A., \& Yoshida, M. 2014. Lesson-study communities. Teaching children mathematics, 10(9), 436-437.

Teacher Institute. 2008. Implementasi Lesson study: Program Pengembangan profesionalitas Pendidik dan Tenaga Kependidikan di Kabupaten Karawang, Kabupaten \& Kota Pasuruan, dan Kota Surabaya. UPI dan Putera Sampoerna Foundation.

Weeks, D. J. 2001. Creating happy memories. Northwest Teacher, 2(2), 6-11.

Zubaidah, S. 2010. Lesson study Sebagai Salah Satu Model Pengembangan Profesionalisme Guru. Pendidikan dan pelatihan nasional dengan tema peningkatan profesionalisme guru melalui kegiatan Lesson study. Malang: Universitas Brawijaya Malang. 